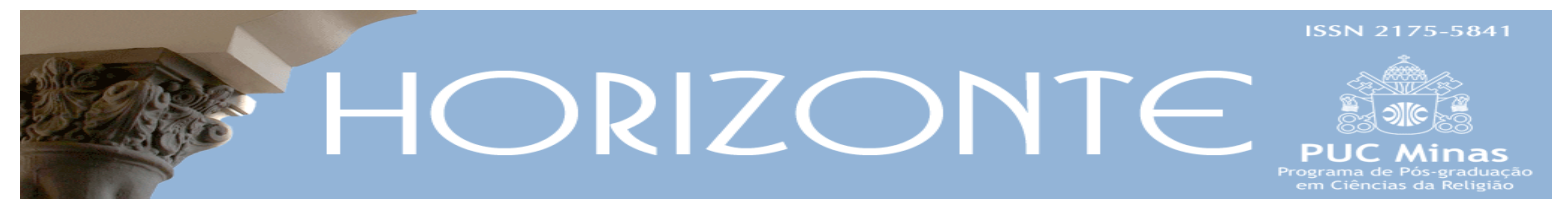

Dossiê: Desafios teológicos do Pluralismo Religioso - Artigo original (c) $\underset{\mathrm{EY}}{\mathrm{C}}$

DOI - 10.5752/P.2175-5841.2015v13n40p2036

\title{
Apologia do fragmento: pertinência teológica da sinfonia adiada de Christian Duquoc ${ }^{1}$
}

\author{
Defense of a fragment: The theological pertinence of the postponed \\ symphony of Christian Duquoc
}

Paulo Sérgio Carrara*

\begin{abstract}
Resumo
O artigo se situa no âmbito do diálogo inter-religioso, um dos grandes paradigmas da teologia atual. Após o Concílio Vaticano II, que tratou da salvação dos não cristãos e dos membros de outras religiões, a teologia aprofundou sua abordagem do tema e apareceram propostas variadas para o diálogo interreligioso. Aos teólogos se impôs o desafio de conjugar a necessidade constitutiva de Jesus Cristo para a salvação de todos e o lugar das outras tradições religiosas no plano de salvação de Deus. A proposta do teólogo católico francês, Christian Duquoc, chamada por ele de sinfonia adiada, reclama atenção por sua singularidade ao afirmar o lado positivo das divisões e fragmentos. Sua abordagem se situa no âmbito da teologia católica surgida após o Concílio Vaticano II, na qual se encontram perspectivas diversas para o diálogo inter-religioso. Sua teologia acentua o papel do Espírito Santo na construção da unidade possível na diversidade dos fragmentos. O presente artigo avalia a pertinência teológica da proposta do teólogo francês para o diálogo inter-religioso.
\end{abstract}

Palavras-chave: Salvação cristã. Diálogo inter-religioso. Chistian Duquoc. Sinfonia Adiada.

\begin{abstract}
The article is situated in the area of inter-religious dialogue, one of the great paradigms of contemporary theology. After the Vatican Council II, which talked about the salvation of non Christians and of the members of other religions, theology deepened this theme and several proposals for an inter-religious dialogue appeared. For theologians it imposed the challenge of joining the constructive necessity of Jesus Christ for the salvation of all and the place of other religious traditions in God's salvation plan. The proposal of the French Catholic theologian, Christian Duquoc, which he called postponed symphony, calls attention to its singularity in affirming the positive side of the divisions and fragments. His approach is situated within the Catholic Theology that emerged after Vatican II, in which there are several prospects for interreligious dialogue. His theology emphasizes the role of the Holy Spirit in building a possible unity in diversity of fragments. The present article evaluates the theological importance of the French theologian's proposal in favor of inter-religious dialogue.
\end{abstract}

Keywords: Christian Salvation. Inter-religious dialogue. Chistian Duquoc. Postponed Symphony.

Artigo recebido em 13 de julho de 2015 e aprovado em 18 de dezembro de 2015.

${ }^{1}$ Esse artigo foi produzido pelo autor no Grupo de Pesquisa Estudos em Cristologia, da Faculdade Jesuíta de Filosofia e Teologia de Belo Horizonte (FAJE).

* Doutor em Teologia pela FAJE. Professor nessa mesma Faculdade e no Instituto Santo Tomás de Aquino (ISTA), em Belo Horizonte. País de origem: Brasil. E mail: pecarraracssr@gmail.com

Horizonte, Belo Horizonte, v. 13, n. 40, p. 2036-2063, out./dez. 2015 - ISSN 2175-5841 


\section{Introdução}

O cristianismo postula a salvação do ser humano em Cristo, cuja encarnação, morte e ressurreição foram experimentadas como decisivas para a humanidade. Por isso, desde os primórdios do cristianismo, os teólogos tematizaram a salvação em Cristo para além das fronteiras da fé cristã. Se Cristo é necessário para todos, como afirma Paulo ( $\mathrm{Rm}$ 5,7), como podem participar da graça salvífica de Cristo aqueles que não professam explicitamente uma fé nele ou nem mesmo ouviram falar dele? Alguns Padres da Igreja tematizaram a existência das “semina Verbi” (sementes do Verbo) que, desprendidas da árvore da vida que é Cristo e carregadas pelo vento do Espírito, chegariam às terras mais distantes para fecundar o solo onde a fé em Cristo não fora ainda semeada.

A história do cristianismo, no entanto, conheceu momentos mais pessimistas quanto à salvação dos não cristãos, nos quais se forjou o famoso axioma "extra Ecclesiam nulla salus". De qualquer modo, permaneceu latente na consciência dos cristãos a convicção segundo a qual a salvação cristã, de algum modo, chegaria àqueles povos aos quais não se havia anunciado o evangelho. $\mathrm{O}$ Vaticano II reconheceu a salvação dos não cristãos e os teólogos, desde então, aprofundaram a intuição fundamental do Concílio. A situação, no entanto, se tornou mais complexa com a nova proximidade das religiões causada pelo fenômeno da globalização, que aproxima várias tradições religiosas, exigindo da fé cristã novas reflexões teológicas condizentes com o momento atual. Propostas teológicas surgem com o escopo de interpretar coerentemente o fenômeno do pluralismo religioso. A reflexão de Christian Duquoc, batizada por ele de sinfonia adiada, emerge como impostação plausível para o diálogo inter-religioso² ${ }^{2}$ Vamos avaliar, neste artigo, sua pertinência. Mas, antes, faz-se necessário compreender,

\footnotetext{
${ }^{2}$ A perspectiva adotada nesse artigo parte, sobretudo, da atual teologia católica do diálogo inter-religioso, sem esgotar as contribuições dos teólogos sobre o assunto. Sendo Duquoc teólogo católico, sua proposta se insere nas intuições surgidas depois do Concílio Vaticano II. Ele reflete, inclusive, sobre a postura e o papel da Igreja frente às tradições religiosas não cristãs.
} 
ainda que brevemente, a afirmação central do cristianismo: Cristo mediador único e universal da salvação.

\section{A mediação única de Cristo}

O Novo Testamento afirma a necessidade da mediação de Cristo para a salvação de todos os seres humanos3. Aqueles que fizeram a experiência da vida, morte e ressurreição de Jesus, as definiram como o ápice da história da salvação e revelação de Deus, cuja autorrevelação, de modo transcendental, realiza-se em toda a história da humanidade, incluindo, assim, as religiões não cristãs (BÖTTIGHEIMER, 2014, p. 303). Mas a história da revelação e salvação se particulariza por meio de um povo que o próprio Deus - YHWY - escolhe para ser mediador de sua presença na história, o povo de Israel, com o qual faz uma aliança. A contínua infidelidade do povo não desfaz sua aliança com Deus, que é sempre reiterada. Os profetas, todavia, anunciam uma aliança definitiva, na qual a vontade de Deus será esculpida não em pedras, mas num coração de carne (cf. Ez 11,19-20). Tal história encontra seu cume em Jesus Cristo. "Muitas vezes e de modos diversos falou Deus, outrora, aos Pais pelos profetas; agora, nestes dias que são os últimos, falou-nos por meio do Filho, a quem constituiu herdeiro de todas as coisas, e pelo qual fez os séculos" (Hb 1,1-20). O que a carta aos Hebreus afirma se encontra em vários trechos do Novo Testamento.

Pedro declara com veemência diante do Sinédrio: "Não há, debaixo do céu, outro nome dado aos homens pelo qual devamos ser salvos” (At 4,11-12). As declarações são assertivas. "Há um só Deus, e um só mediador entre Deus e os homens, um homem, Cristo Jesus, que se deu em resgate por todos" (1 Tm 2,5). Segundo Paulo, Deus reconciliou consigo os homens por meio de Cristo (2 Cor 5,19). A abundância da graça e o dom da justiça emergem na existência humana por meio de um só, Jesus Cristo (Rm 5,17). João Batista, no evangelho de João,

\footnotetext{
${ }^{3}$ Os textos bíblicos escolhidos para fundamentar a argumentação não são aqui estudados a partir de uma exegese científica rigorosa, que poderia evidenciar conflitos de interpretação. Por outro lado, são textos nos quais a teologia cristã católica e outras teologias cristãs se apoiam para afirmar a necessidade da mediação única de Cristo para a salvação de todos.
} 
reconhece em Jesus o cordeiro de Deus que tira o pecado do mundo (Jo 1,29) e quer que todos tenham a vida em abundância (Jo 10,10). Afinal, "o Pai enviou seu Filho como salvador do mundo" (1 Jo 4,14). Os evangelistas não se cansam de apresentar Jesus como salvador. "Ela dará à luz um filho e tu o chamarás com o nome de Jesus, pois ele salvará o povo dos seus pecados" (Mt 1,21). Salvador enviado pelo próprio Deus (Lc 2,11; Jo 4,42; At 5,31; Ef 5,23; Fl 3,30; 2Tm 1,10; Tt 1,$4 ; 2 \mathrm{Pd} 1,1.11 ; 2,20 ; 1$ Jo 4,4). Ele dá sua vida para resgatar a muitos (cf. Mt 20,28). A salvação é obra de Deus Pai (Lc 1,47; 1Tm 1,1; 2,3; 4,10; Tt 1,3; 2,10; 3,4; Jd 25) e de seu Filho, o único mediador, aquele em quem Deus Pai quer que todos cheguem à salvação (1Tm 4,10).

A vida de Jesus foi marcada pela pregação do Reinado de Deus. Reinado cuja realização se dá quando a humanidade acolhe Deus como soberano. O Reino é, na verdade, o sonho de Deus para a humanidade e se resume no amor, na justiça, na paz e na fraternidade. Quando Deus reina na vida humana, a salvação acontece. A recusa da proposta de Jesus o levou à condenação injusta, mas ele fez da sua morte na cruz o ato final de sua vida em favor dos homens. Deus Pai não permaneceu indiferente à entrega de Jesus, mas a acolheu, tornando o mistério pascal do Filho o evento salvífico por excelência. A ressurreição de Jesus faz a vitória do Reinado de Deus irromper na história, ou seja, a vitória definitiva de Deus sobre a injustiça, o pecado e a morte. Ao ressuscitar Jesus, Deus Pai arranca do absurdo seu Filho. Em Deus, seu Pai, Jesus reencontra a realização plena de sua história terrena, na qual anunciou e realizou o Reino de Deus. A ressurreição desvela o sentido da vida e morte de Jesus e lhes confere uma validade irrevogável. Ao ressuscitá-lo, Deus dá razão ao crucificado e mostra que sua solidariedade com os pecadores e os que sofrem coincide com a vontade de Deus. Ao ressuscitar Jesus, Deus antecipa aquilo que se manifestará no fim: a vitória da justiça, a fraternidade universal como realização plena do Reino (KESSLER, 1989, p. 252253). 
Mas a salvação não aconteceu de maneira extrínseca ao mistério pessoal de Jesus, mistério filial. O mediador do Reino de Deus é seu próprio Filho. A salvação acontece no momento em que o Filho de Deus assume a condição dos homens a salvar, sua humanidade pecadora, sem que ele mesmo seja pecador. "Pela ação do Pai e pela própria obediência, Cristo, enquanto homem, chega à perfeição da união com Deus e à perfeição da união com os homens na solidariedade mais completa" (LADARIA, 2009, P. 66). A salvação dos homens depende da própria humanidade de Cristo. Ele se rebaixa, não se apega à sua divindade, assume a condição de escravo (Fl 2,2-11) e precisa ser exaltado e glorificado pelo Pai para adquirir a glória que antes dos tempos possuía. Enquanto homem, foi provado em tudo, exceto no pecado ( $\mathrm{Hb}$ 4,15). O próprio Cristo fez, portanto, o percurso da salvação na nossa humanidade. A ressurreição constitui Jesus Filho de Deus com poder $(\mathrm{Rm}$ 1,3-4), ele se torna Senhor de tudo (Fl 2,11), é elevado à direita do Pai (Mc 16,19; At 2,34). Ao ressuscitá-lo, o Pai o gera para a plenitude de sua filiação (At 13,33; $\mathrm{Sl} \mathrm{2,7;} \mathrm{Hb} 1,5 ; 5,5)$. O Pai acolhe o Filho, gerando-o no Espírito para a plenitude divina que ele faz habitar corporalmente no Filho $(\mathrm{Cl}$ 2,9). A ressurreição como geração significa fazer habitar corporalmente em Jesus a plenitude da divindade. Se a vida humana de Jesus tem a ver com a Trindade, quer dizer que sua humanidade se torna parte irrevogável de seu ser e precisa ser incorporada à divindade. Por isso pode o Novo Testamento falar da ressurreição como geração (LADARIA, 2005, p. 91). A filiação divina de Jesus conheceu uma história, cuja plenitude se dá no mistério pascal, quando o Pai o gera para a plenitude de sua filiação na condição dos homens a salvar, ou seja, na humanidade, agora glorificada em Jesus (DURRWELL, 2006, p. 29). A salvação dos homens depende, pois, da plenitude de Cristo, é participação na humanidade glorificada de Jesus (Jo 1,16).

O que Jesus dará aos homens coincide com o que recebe do Pai na sua ressurreição, a salvação na sua humanidade. Jesus foi salvo da morte pela ressurreição e recebeu na sua humanidade a plenitude da salvação. Nele a humanidade foi divinizada. A divindade desponta como a substantia salutis da 
qual a humanidade participa pela mediação de Jesus (LADARIA, 2009, p. 66-70). A humanidade de Cristo, portanto, não diz respeito apenas à sua vida histórica, ela perdura para sempre no Cristo, glorificada e divinizada. $\mathrm{O}$ encontro dos homens com Deus depende da eterna humanidade de Cristo. Afinal, o Verbo encarnado se fez homem e exatamente porque se fez homem se tornou o mediador necessário e eterno da salvação, não só no passado, mas por toda a eternidade (RAHNER, 1969, p. 57).

Mas o Novo Testamento não afirma apenas a mediação de Cristo em vista da salvação. A própria criação finca nele as suas raízes. Ele é também mediador da criação. O mundo carrega uma marca cristológica, uma vez que nele foi criado (1 Cor 8,6; Cl 1,15-20). A carta de Paulo aos Colossenses aprofunda essa perspectiva, apontando Cristo como princípio e finalidade da criação ( $\mathrm{Cl}$ 1,15-20). Nele o mundo encontra uma unidade de origem e de destino. O plano de Deus consiste em realizar a criação como uma unidade em, por e para Cristo. Cristo é salvador porque aparece no início como criador. Se tudo foi criado em e para Cristo, deve-se afirmar que ele é o fundamento último da realidade, o que garante a permanência no ser de todo o criado. Nele a realidade encontra harmonia, unidade, coesão (DE LA PEÑA, 1988, p. 69-75). O destino da criação se desvenda a partir de Cristo. O plano de Deus é tudo recapitular em Cristo, fazendo que toda a realidade criada conflua para ele. A Igreja vive deste projeto, cabendo-lhe como tarefa a propagação do plano divino da salvação, para que Cristo seja não somente cabeça da Igreja, mas do universo. A unidade da Igreja se torna sacramento da unidade cósmica. A entrada de Cristo na história a faz entrar na sua última etapa. O mundo, desde já, se encontra no dinamismo da nova criação (2 Cor 5,17; Gl 6,15) (DE LA PEÑA, 1988, p. 77-78).

O prólogo de João (Jo 1) evidencia a unidade indissolúvel entre a palavra divina criadora de Gn 1 e a palavra encarnada, o Logos, em quem a revelação e salvação de Deus chegam à sua plenitude. O Logos garante a vitalidade e a coerência da criação toda (DE LA PEÑA, 1988, p. 81-82). Passado, presente e 
futuro convergem para o mesmo Cristo, pois tudo foi criado nele e para ele, tudo subsiste nele e tende para aquele que consumará a história. A vocação do ser humano se resume na comunhão com Deus em Cristo, porque Deus o quis em Cristo, o salvou em Cristo e fez de Cristo a plenitude do criado. A salvação vai além do perdão dos pecados, pois o plano de Deus é elevar a si o ser humano em Cristo. O pecado tornou a salvação redentiva, porque o ser humano, historicamente, rompeu sua relação com Deus. A graça se torna, assim, oferta de salvação que emana desde a cruz, gesto final de Jesus em vista da salvação. Mas antes mesmo do surgimento histórico do pecado, o ser humano fora querido por Deus em Cristo, em quem tudo será recapitulado (cf. Ef 1,10). O pecado não destruiu o plano de salvação de Deus, mas evidenciou ainda mais o seu amor, que chega a cada ser humano como graça recriadora e reconciliadora (2 Cor 5,19).

Tudo foi submetido a Cristo (Ef 1,22; 1 Cor 15,24-28) e a salvação que nele se efetiva se destina a todos os homens, sem exceção (Mt 28,19; Mc 16,15-16). Sua ação salvífica abraça o universo inteiro. Ele é, de fato, o único caminho para Deus. Quando sua oferta é aceita pelo Pai na cruz, o Pai está agindo não somente a favor de seu Filho, mas da humanidade. Ao ser glorificado na condição dos homens a salvar, por meio da ressurreição, o relacionamento de Deus com os homens muda radicalmente. O Reino que Jesus havia anunciado tornou-se definitivo por sua ressurreição. A vida do ser humano tem sentido na medida em que realiza na história o que aconteceu na ressurreição de Jesus. Ao antecipar para a história a vitória de Jesus sobre a morte, a injustiça e o pecado, Deus inaugurou a última etapa da história da salvação (KESSLER, 1989, p. 262).

A ação de Deus em Jesus se universaliza no Espírito, porque a salvação que nos trouxe o Crucificado e Ressuscitado atua no mundo por meio do Espírito. A história caminha na direção da manifestação total e cósmica da ressurreição. A ação de Deus no seu Filho presente no Espírito introduz o mundo em uma nova realidade, na experiência atual da páscoa, porque o Espírito é quem produz hoje os frutos da ressurreição. A salvação depende, também, do Espírito Santo. Cristo é a 
salvação, mas ela se estende pela história através do Espírito, dom fundamental do Ressuscitado.

Os dados do Novo Testamento não deixam dúvida ao apresentar Jesus como o fundamento último de todo criado e o mediador único da salvação. A afirmação, no entanto, de que Jesus - um particular - é o salvador de todos sempre levantou questões à teologia, mormente no atual contexto do diálogo inter-religioso. Ladaria as formula com clareza, perguntando-se se, de fato, seria desvalorizar as religiões e a figura de seus salvadores a permanente insistência sobre a medição única e exclusiva de Cristo. Antes a reflexão teológica se centrava na salvação de todos por Cristo. Hoje, a questão se deslocou para o significado das outras religiões no plano da salvação de Deus e o lugar de Cristo e da Igreja nesse plano. Seria, no contexto atual, desvalorizar as outras religiões a afirmação segundo a qual o que de bom há nelas tem a ver com Jesus, o Filho de Deus, e a salvação que trouxe para a humanidade (LADARIA, 2009, p. 96)?

\section{A sinfonia adiada de Duquoc}

Na constelação das teologias das religiões, a proposta do teólogo francês Christian Duquoc irradia brilho próprio, uma vez que se fundamenta não na busca da unidade doutrinal, mas na "fecundidade da divisão". O teólogo parte de uma constatação óbvia para o observador atento: "A reunião de todas as religiões num único propósito continua lindo sonho. O movimento atual de diálogo não produziu unificação alguma dos fragmentos esparsos" (DUQUOC, 2008, p. 143). Por outro lado, ao mesmo tempo em que professamos nossa fé no domínio de Cristo sobre o universo e a história, tal domínio permanece um enigma. O senhorio de Cristo que jorra por sua ressurreição não se manifesta com clareza absoluta no tempo intermediário entre sua vitória sobre a morte e o Reino definitivo. Esse tempo intermediário se caracteriza por divisões entre as religiões. Se Cristo é o único mediador da salvação, sua ação no mundo e na história se realiza de modo 
fragmentado, uma vez que ainda não produziu a comunhão desejada entre os seres humanos e suas religiões. As divisões se nos impõem como primeira evidência. Nesse caso, “em vez de deplorá-las, não é preciso, ao menos por hipótese, pensálas fecundas" (DUQUOC, 2008, p. 143)?

A soberania do Ressuscitado se realiza na história através do Espírito Santo, dom fundamental de sua ressurreição. O Cristo da glória age pelo Espírito, cuja função é conduzir a humanidade à comunhão, num só corpo, o de Cristo (1 Cor 12). Ele trabalha no mundo para tornar realidade o sonho de Jesus: "Que todos sejam um" (Jo 15-17). O Espírito não divide, mas suscita comunhão. Nesse caso, as divisões seriam contrárias à tarefa do Espírito e seu trabalho no mundo. No entanto, o modo como a Escritura apresenta a missão do Espírito convida a julgamento menos negativo das divisões. As fronteiras do Espírito não são claramente definidas. Jesus, no evangelho de João, fala do Espírito destacando a imprevisibilidade de sua ação. "O vento sopra onde quer e ouves o seu ruído, mas não sabes de onde vem nem para onde vai. Assim acontece com todo aquele que nasceu do Espírito" (Jo 3,8). Sua ação, segundo o dito de Jesus, revela-se instável e imprevisível. Não se determina sua origem e o término do movimento de sua ação. Uma vez que é enviado por Cristo, sua dinâmica vital se caracteriza como sopro de liberdade e amor em vista da irrupção do Reino, o que não quer dizer que sejamos capazes de mensurar sua ação. Ela ultrapassa nossas medidas e, em sua atividade incessante, abala seres humanos e mundos, sempre segundo sua vontade e não como força cega. Seu trabalho no mundo produz seus efeitos, pois ele é vida (DUQUOC, 2008, p. 146-147).

O Espírito aparece em Paulo estreitamente ligado ao amor fraterno (1 Cor 12-14). Ele é o autor dos carismas e suscita o amor como o carisma mais excelente. O amor a Deus e ao próximo resume a lei. E a ignorância sobre Deus e Cristo se suplanta com o amor solidário aos mais necessitados (Mt 25,31-46). Amor e liberdade são frutos do Espírito. O Espírito, que unge Jesus para sua missão e o ressuscita, garante a presença de Jesus e a continuidade do Reino que ele inaugurou, cujo ponto culminante se encontra na fraternidade. E Jesus garante 
que, depois de sua partida, enviará o Espírito para conduzir os discípulos a uma verdade ainda não imaginada. A atividade do Espírito se revela, assim, criativa e não repetitiva, criadora e não conservadora. Ele é promessa (Ef 1,13). Não se contenta com uma harmonia imóvel imposta uma vez para sempre. O próprio Jesus chama a atenção dos discípulos para que não se impacientem com a demora do Reino (Mt 13,24-31). Não cabe aos discípulos antecipar o julgamento. A separação do joio e do trigo pertence ao final dos tempos (Mt 13,37-42). A paciência se fundamenta na esperança posta em Cristo (1 Tm 1,3) e em sua promessa (Hb 10,36). O Espírito garante o cumprimento da promessa (Ef 1,13). Antecipa sinais da promessa para o tempo intermediário, mas não apressa o passo, dá tempo ao tempo, deixando avançar a maturação. Lentamente, conduz ao caminho da verdade plena (Jo 16,13), mas mantendo inacabamento provisório (DUQUOC, 2008, p. 149-152).

O retardamento da unidade final emerge da ação do Espírito, para não apagar a chama que ainda fumega (Mt 12,20). Em Pentecostes, o Espírito produz unidade, porém não elimina as línguas, que estão na base das divisões entre os povos. Cada um entende no fragmento da sua própria língua a boa notícia da ressurreição de Cristo. As divisões não expressam, necessariamente, hostilidade entre as diferenças, podem estar a serviço da riqueza das diferenças, que exigem tolerância. O Espírito une curando inimizades e não suprimindo as singularidades. Neste caso, "forçar a unificação tornando-a cultural, religiosa e institucionalmente perceptível passa por cima do tempo da maturação de cada singularidade pessoal e coletiva” (DUQUOC, 2008, p. 153). A humanidade segue vagarosamente rumo à unificação no Reino definitivo. O Espírito a conduz não eliminando as divisões, mas propondo uma meta comum, ainda não totalmente desvelada. Seu caminho é o da verdade, no entanto, essa não pode ser prematuramente conquistada e imposta por um grupo ou instituição. Sua ação possui caráter inacabado no que diz respeito à verdade. "Nenhum conceito, nenhum dogma, nenhum grupo, nenhuma Igreja pode totalizá-la; ela escapa de nosso domínio” (DUQUOC, 2008, p. 154). As 
instituições e os grupos têm, às vezes, pretensões absolutas, como se já tivessem chegado ao termo do processo histórico. O Espírito resiste-lhes e se opõe à pretensão de querer a verdade plena, aqui e agora. Ele não apressa a unidade final que levaria à imposição autoritária da verdade. Admite hesitações e dúvidas. O próprio Jesus não confiou aos seus discípulos a verdade plena, mas prometeu o Espírito para conduzi-los a ela (Jo 16,13).

O Espírito, por sua vez, convida os discípulos à desafiante busca da verdade sem revelá-la antes da hora. A verdade total à qual ele conduz os homens passa por um saudável não-saber. Garante a presença de Deus e de seu Cristo, mas Deus continua indisponível. A verdade se faz presente de forma fragmentada e não previamente determinada. Deus não permanece à nossa disposição ao lado de qualquer outro bem. Não renunciamos à verdade que Deus é, mas nossa percepção da sua verdade se dá de forma humana, finita, portanto necessariamente fragmentada. À luz da espera de Deus testemunhada pelo Espírito, as divisões temporárias, mormente as religiosas, só seriam destruidoras e negativas se provocassem hostilidade, guerra e ódio. Mas isto só acontece quando um fragmento se impõe como totalidade da verdade (DUQUOC, 2008, p. 155).

Ao constatarmos que o Espírito não antecipa a sinfonia final e respeita os fragmentos, não estaríamos, por outro lado, relativizando a universalidade da salvação em Cristo? Teria o Espírito economia própria, diferente daquela revelada em Cristo? A ação do Espírito apresentaria dependência somente do Pai? A fé cristã afirma a mediação única de Cristo, amplamente atestada no Novo Testamento, como se mostrou. A vontade de Jesus expressa na oração é clara: “que todos sejam um. Como tu, Pai, estás em mim e eu em Ti, que eles estejam em nós, para que o mundo creia que tu me enviaste" (Jo 17,21). Jesus é o enviado do Pai que atua pelo Espírito e o envia para que todos formem nele uma unidade, que chamamos o corpo de Cristo. Aqueles que pertencem a esse único corpo não se igualam a Cristo, cabeça do corpo, porque ele é o Filho unigênito no qual os outros são adotados pela configuração a ele. E Jesus continua sempre aquele que se encarnou, o Galileu, que introduziu a humanidade na divindade. Os evangelhos 
mostram a missão de Jesus no contexto do judaísmo. Ele é filho de Israel e o seu povo é o destinatário primeiro do anúncio do Reino. Mas a missão de Israel não exclui os outros povos. No seu meio, Israel é chamado a ser luz das nações, testemunhando a bondade e grandeza de Deus. Jesus não despreza os estrangeiros. Aliás, um pagão recebe grande elogio de Jesus: "Eu vos digo que nem mesmo em Israel encontrei tamanha fé" (Lc 7,1-9). Em muitos episódios de sua vida, Jesus se mostra acolhedor com os estrangeiros. Os samaritanos eram considerados heréticos pelos judeus, mas o próximo da parábola que Jesus conta é justamente um samaritano, cujo comportamento supera o do sacerdote e o do levita (Lc 10,29-37).

A marcha da história sustentada pelo Espírito Santo conduz, necessariamente, a Cristo, afinal, ele é “o alfa e o ômega, o primeiro e o último, o começo e o fim" (Ap 22,12-13). Cristo emerge como o fim último da história, cujo andamento não é caótico, mas tem destino certo. Toda a história da humanidade tende para Cristo, o que não torna possível especificar minuciosamente como se está manifestando hoje a finalidade última da história. A Igreja é "sacramento da salvação universal" (LG 48) operada por Cristo, mas tal salvação vai muito além da Igreja pela ação do Espírito. Ele é a medida da presença de Deus no mundo, não a Igreja que, aliás, não só oferece suas riquezas ao mundo, mas também recebe muito dele (LG 3). As relações da Igreja com o mundo e suas religiões não precisam ser marcadas pela hostilidade e rejeição. O mundo se constitui de fragmentos, tal constatação não contradiz a verdade segundo a qual Cristo é alfa e ômega (Ap 22,12-13). O Reino inaugurado por Jesus já está presente, mas de maneira velada e não totalmente evidente; ele se mostra e se esconde (DUQUOC, 2008, p. 166).

Duquoc propõe a metáfora da sinfonia adiada para explicitar seu ponto de vista teológico. Tal sinfonia é executada por maestro e compositor invisíveis. As religiões representam composições variadas. A partitura futura e os instrumentos permanecem velados, não os conhecemos totalmente. O texto musical permanece 
em parte desconhecido e não estamos em condições de saber como se harmonizam seus elementos dispersos. As imagens e sinais do Reino nos permitem certa aproximação às intenções do compositor. Mas ele não se mostra, não desvela totalmente o seu rosto. Quando se manifestar, num tempo que não determinamos, as composições dispersas serão unificadas numa partitura única. Cada religião segue seu próprio texto musical, sem que se saiba quando e como se integrará aos outros, para formar um conjunto harmonioso (DUQUOC, 2008, p. 166).

Para o teólogo, a Igreja não julga ou antecipa o modo como se unificarão em Cristo as variadas composições que ressoam ao mesmo tempo. As criações musicais expressam a proximidade e a distância de Deus. E só há um perigo a evitar: considerar sua composição a sinfonia total. Nesse caso, a riqueza dos fragmentos seria eliminada, afinal,

retirando-se Cristo favorece a elaboração de composições múltiplas; elas constroem-se sem pressa. Ao esgotar o tempo, ele dará à orquestra capacidade multiforme e unidade não esperada. $\mathrm{O}$ adiamento da sinfonia dá aos fragmentos a possibilidade de exprimir a originalidade e a riqueza deles (DUQUOC, 2008, p. 166).

E qual o lugar da Igreja ou do cristianismo no meio da diversidade das criações musicais diversas, representadas pelas tradições religiosas? A metáfora, aqui, apresenta um limite, porque os cristãos conhecem desde já a identidade do maestro, enquanto os outros explicitamente nada sabem dele ou mesmo não o aceitam. Como entrar no jogo do não-saber conhecendo a identidade do maestro? Tal conhecimento não poderia ser tomado como privilégio que poria outras tradições em desprestígio? A Igreja é sacramento de Cristo e de sua salvação, porém a medida da presença de Cristo é o Espírito, não a Igreja. Se ele age na Igreja, mormente na celebração dos sacramentos, isso não quer dizer que não aja fora dela. Não cabe à Igreja adiar a sinfonia, quem o faz é o próprio Deus e à Igreja resta um caminho de humildade, uma vez que ignora o modo de o Espírito conduzir a história das tradições religiosas para seu termo, a sinfonia final. A questão do adiamento é mais cristológica que eclesiológica, embora isso obrigue a 
Igreja a repensar sua missão, que inclui a acolhida da singularidade dos fragmentos e o respeito dos vários caminhos que conduzem a uma mesma realização (DUQUOC, 2008, p. 167).

Duquoc recorre à ação do Espírito para salvaguardar o que há de positivo nas religiões segundo a identidade própria de cada uma. A ação do Espírito se encontra na maturação do fragmento. O Ressuscitado, ausente, se retrai e permite que atue o Espírito, mas evitando a integração prematura dos fragmentos na instituição que o confessa. Os fragmentos são respeitados no seu processo de maturação rumo à sinfonia final e só uma regra se lhes impõe: que a defesa da identidade de um fragmento não se absolutize a ponto de impedir o mesmo movimento nos outros fragmentos. Tal regra garante a coexistência pacífica e respeitosa entre as tradições, culturas, nações e religiões. Só a abertura aos outros em vista da boa convivência assegura que a sinfonia não é ilusória. As diferenças serão superadas num futuro incalculável, na sinfonia adiada e, por enquanto, inimaginável (DUQUOC, 2008, p. 168-169).

O teólogo francês, com sua proposta da sinfonia adiada, busca, ainda, especificar o desafio para a Igreja que confessa o Cristo e é, no mundo, sacramento da salvação. Segundo sua opinião, o reconhecimento dos fragmentos não compromete sua vocação, a ser vivida, no entanto, na humildade e renúncia a querer se compreender como o todo, apresentando-se como lugar único do Espírito e delegada do seu Senhor. Para isso, ela terá que suportar os limites da história, assim como fez o próprio Jesus, sem querer saltar os tempos da maturação. Afirma Duquoc:

Parece-me inútil, portanto, assinalar um horizonte comum que se suporia favorecer o diálogo propondo base mínima de acordo. É mais desejável que cada fragmento aprofunde sua lógica sem obstruir seu intuito universal, vazio, por enquanto, de todo conteúdo capaz de unificar o diverso religioso (DUQUOC 2008, p. 170) 
A Igreja não renuncia ao seu horizonte de esperança quanto a um destino grandioso ao qual é chamada pelo seu Senhor, mas ela desconhece o desenrolar das relações no ambiente em que vive sua vocação. Ela conserva certa ignorância quanto ao seu futuro e vive sua vocação denunciando a injustiça e a violência. E se por um lado não há horizonte comum por falta de um conceito totalmente confiável à nossa disposição para identificá-lo, há, por outro, intercâmbio entre os fragmentos, porque lidam com as mesmas questões: a beleza do mundo, o trágico da história, a obstinação dos justos na luta contra o mal. Cada fragmento interpreta os mesmos problemas à luz de suas respectivas tradições e o intercâmbio entre elas se revela positivo sob diversos aspectos, sobretudo sob o da busca pela justiça. Mas se evitam as sínteses doutrinais prematuras, que levariam ao imperialismo institucional (DUQUOC, 2008, p. 170).

As experiências religiosas das várias tradições se aproximam em muitas dimensões. A oração, por exemplo, atesta o desejo comum de superação da injustiça, do infortúnio e a alegria que a beleza do mundo e a busca da justiça despertam no coração do ser humano. A interdependência entre os fragmentos se integra perfeitamente na nova ordem política mundial, que não permite mais o fechamento sobre a própria tradição. A nova ordem política convida todos a uma troca fecunda capaz de superar a violência e evitar desastres mundiais. As nações e suas religiões têm a grave responsabilidade da construção da paz e da justiça mundiais, mesmo sabendo que só serão alcançadas num futuro indeterminado, o da sinfonia adiada. A Igreja, neste novo contexto, redimensiona sua missão de manter a fé que a faz viver, sem renunciar à verdade do Cristo que atua pelo Espírito. Apenas renuncia à tentação de antecipar o tempo de modo totalitário, juntando, desde já, os fragmentos numa unidade imposta. A renúncia a ter a última palavra soa problemática para muitos, mas ao manifestar sua modéstia, ela poderia admitir que a ausência de seu Senhor é benéfica para todos. Cristo não antecipa a execução da sinfonia, ele a adia para que as divisões e os fragmentos sejam vistos como lugares paradoxais da esperança (DUQUOC, 2008, p. 172-173). 


\section{Pertinência teológica da sinfonia adiada de Duquoc}

A proposta de Duquoc se situa no contexto da teologia das religiões, na qual emergem várias propostas em vista de um olhar positivo sobre o pluralismo religioso, dado objetivo e emergente na cultura pós-moderna e globalizada, que se caracteriza pelo respeito às diferenças e pela tolerância. Passaram-se os tempos da hegemonia sociocultural da Igreja e, para muitos, estamos numa era pós-cristã, uma vez que o substrato cristão da cultura e da sociedade desapareceu em muitos lugares e se extingue rapidamente em outros. O traço da religiosidade pósmoderna se alicerça na subjetividade capaz de produzir diversos significados e criar múltiplas referências (HERVIEU-LÉGER, 2008). O mundo se pluralizou e o pluralismo religioso, considerado negativo durante séculos, passa a ser visto positivamente. E não há dúvida de que o diálogo inter-religioso se impõe como um dos horizontes mais importantes da teologia atual. A proposta do teólogo francês Duquoc apresenta pertinência própria e prováveis limites.

A Igreja deixou para trás sua posição exclusivista, segundo a qual o cristianismo se impunha como religião verdadeira. Nessa concepção, todas as outras religiões seriam falsas e não poderiam ser vistas como mediadoras de salvação. A Igreja se considerava a única depositária da revelação e a única mediadora da salvação - única mediadora do único mediador, Cristo. Só aqueles que explicitamente pertencessem a ela seriam salvos, porque extra Ecclesiam (Jesum Christum explicitum) nulla salus. Por outro lado, sempre houve na Igreja os que pensaram a salvação dos não cristãos, uma vez que a vontade salvífica universal de Deus aparece como dado incontestável nas Sagradas Escrituras. A teologia cunhou a ideia de batismo de desejo como uma via possível de salvação (LIBANIO, 2000, p. 413-414). Afinal, "se Deus exclui a maioria da humanidade das possibilidades de salvação, ele não é nada mais do que um déspota terrível" (BÖTTIGHEIMER, 2014, p. 307). 
O exclusivismo acabou evoluindo para o inclusivismo. Tal posição teológica, adotada pelo Vaticano II, busca conjugar o caráter absoluto da revelação cristã com o dado objetivo da existência de outras religiões. O Concílio admite a possibilidade da salvação em outras religiões e fora de qualquer uma delas. Abre, assim, nova perspectiva para a salvação universal (NA 1; AG 7, 9; LG 16; GS 22). A Igreja reconhece a mediação salvífica das religiões para seus adeptos sem, no entanto, atribuir-lhes uma autonomia salvífica, que depende exclusivamente de Cristo. Enquanto sacramento da graça da salvação e prolongamento de Cristo na história, aponta para a salvação de Deus que está agindo no mundo para além de suas fronteiras institucionais. Neste contexto, Rahner cunhou o conceito de "cristianismo anônimo", segundo o qual a existência de muitas pessoas carrega, implicitamente, o que a Igreja afirma explicitamente sobre o evangelho, centrado no amor vivido como resposta ao apelo de Deus em Cristo. Toda salvação se refere a Cristo e à Igreja. O ser humano é salvo pela graça de Cristo presente na Igreja. Cristo permanece, portanto, mediador constitutivo da salvação (LIBANIO, 2000, p. 415-418). A proposta do teólogo alemão conheceu importantes críticas, porque, na opinião de alguns, ela desvaloriza a conversão a Cristo e a pertença explícita à Igreja (BALTHASAR, 1998, p. 234-235). Após o concílio Vaticano II, no entanto, a posição de Rahner ganhou adeptos.

Recentemente, a reflexão teológica avançou e a posição inclusivista sofreu questionamentos significativos por defender o caráter único e indispensável de Jesus Cristo para a salvação, o que tornaria o cristianismo superior às outras religiões. O pluralismo passou a defender a perspectiva segundo a qual Deus deve ser visto como a referência para a salvação, e não Cristo. Todas as religiões convergem para Deus e aqui se encontra seu aspecto mais crucial. O cristianismo, nesse caso, perde sua pretensão de superioridade e se torna uma religião entre outras, porque todas conservam, a seu modo, a autorrevelação de Deus. As religiões são, pois, igualmente verdadeiras e caminhos válidos para Deus. Os adeptos dessa posição defendem o pluralismo de princípio que se expressa num paralelismo simétrico entre as religiões, uma vez que as consideram caminhos 
autônomos de salvação. O lugar de Cristo segundo tal proposta se relativiza, pois ele seria o caminho para os cristãos, não para os hinduístas, mulçumanos, judeus. As visões teológicas matizam de maneiras diversas a figura de Cristo, mas normalmente tendem a considerar Jesus não mais o "mediador constitutivo" da salvação, ainda que ele seja visto por alguns como "normativo" sobre o modo como Deus trata a humanidade. (LIBANIO, 2000, p. 421-424). Passa-se, assim, de um cristocentrismo da salvação a um teocentrismo. Para alguns, o pluralismo de princípio se apresenta como caminho necessário para o diálogo inter-religioso, o que deveria levar à superação dos bloqueios que não permitem reconhecer a revelação de Deus fora do cristianismo como normativa (TEIXEIRA, 2004, p. 259). A cristologia pluralista, porém, dificilmente se harmoniza com a concepção cristã da revelação, que afirma a unicidade de Jesus Cristo (BÖTTIGHEIMER, 2014, p. 317).

A proposta de Duquoc permanece fiel ao dado fundamental do Novo Testamento, segundo o qual Jesus é a boa nova da salvação para toda a humanidade. Embora ele seja "um particular" do ponto de vista religioso e cultural, a salvação realizada por ele e nele conserva seu valor universal e constitutivo. A Igreja apenas se submete à revelação de Deus em Jesus Cristo e a transmite às novas gerações. Tal revelação não permite relativizar a verdade do mistério pascal de Cristo como ato escatológico definitivo e vitorioso de Deus a favor de todos os homens. Tal mistério está aberto aos que não pertencem às suas fileiras. O Concílio afirma que a vocação do ser humano é uma só: comunhão com Deus em Cristo. Por isso o Espírito Santo concede a todos, de um modo conhecido só por Deus, a possibilidade de participar do mistério pascal de Cristo (GS 22). Aliás, "a inclusão da humanidade inteira em Cristo (criação, encarnação, redenção) é o pressuposto de todas as afirmações do Novo Testamento sobre nossa salvação" (CARDEDAL, 2008, p. 528). 
Duquoc se esforça, no atual contexto do diálogo entre as religiões, para pensar e propor uma teologia da salvação em Cristo que seja inclusiva das outras tradições religiosas e que valorize suas particularidades como ação do Espírito, sem considerá-las, por outro lado, “cristianismo anônimo”, conceito cunhado por Rahner, para o qual aquilo que os cristãos vivem explicitamente, os não cristãos o fazem implicitamente. Para o teólogo francês, tal proposta se revela hoje insatisfatória, porque somente os cristãos conhecem e decifram em profundidade o que os outros testemunham. O que há de positivo nas outras tradições se encontra naquilo que os cristãos julgam como tal. A singularidade de cada tradição religiosa permanece, assim, ignorada. Os fragmentos deixam de ser respeitados na sua diferença, cujo significado positivo está somente no seu elo oculto com Cristo. Tal posição acaba caindo na pressa de integrar cada fragmento na sinfonia última. Essa, no entanto, inclui, segundo o Concílio, a evolução autônoma do mundo, visto como história de salvação (DUQUOC, 2008, p. 168). O Concílio não descreve o modo como tal evolução chegará à sua plenitude final. A salvação se dilata na história pela ação imprevisível do Espírito, afinal, ele é como o vento e não nos permite saber de onde e vem nem para onde vai (Jo 3,8). Cabe a ele salvaguardar a positividade de cada fragmento.

A posição de Duquoc quanto à verdade pode causar desconforto. O teólogo enfatiza que "nenhum conceito, nenhum dogma, nenhum grupo, nenhuma Igreja pode totalizá-la; ela escapa de nosso domínio" (DUQUOC, 2008, p. 154). Aliás, considerar-se dona da verdade no passado não foi benéfico para a Igreja. A pretensão de ser depositária absoluta da verdade engendrou violência e injustiça, escrevendo uma das páginas mais obscuras da história da Igreja. O teólogo francês denuncia a estreita - e infeliz - relação entre verdade e violência (DUQUOC, 2001, p. 21). Quem tem a verdade acaba querendo impô-la em vista de uma hegemonia forçada, que mata as diferenças e desconsidera o valor dos fragmentos. A posse da verdade fomenta o imperialismo da conquista e do absolutismo. Duquoc, porém, não questiona a verdade da salvação em Cristo, apenas afirma que ela se estende na história pela ação do Espírito presente em outras tradições, uma ação livre e 
surpreendente. Se, por um lado, "em Jesus Cristo a verdade escatológica definitiva sobre Deus, sobre o ser humano, sobre o mundo e sobre a história está presente" (BÖTTIGHEIMER, 2014, p. 341), por outro, nosso acesso a ela carrega o limite da história e da finitude. Rahner afirmou com propriedade:

O homem não consegue mais tão facilmente reconhecer na religião constituída concretamente, com suas inúmeras fórmulas, usos, prescrições e regras, a forma concreta e obrigatória de Deus e o caminho necessário para sua salvação. (RAHNER 1970, p. 154)

O teólogo alemão reconhece que, para o homem de hoje, uma dogmática complicada parece dizer demais sobre Deus. Ela se mostra exageradamente racionalista e excessivamente doutrinária. As pessoas hoje são mais sensíveis ao mistério imenso de Deus, que não cabe em nenhum conceito (RAHNER, 1970, p. 155). Ainda que Deus tenha se aproximado de nós em verdade e amor, em Cristo e no Espírito, ele permanece mistério indecifrável que só conhecemos com profundidade quando o amamos. O mais importante não é objetivar Deus, mas encontrá-lo, pois o ato da transcendência não coincide com a descrição objetiva desse ato. A inteligência humana não decifra Deus, por mais que a teologia possa e deva - falar dele a partir da revelação em Cristo. Deus permanece o mistério sem nome e não delimitável, oferecendo-se ao ser humano como horizonte absoluto da transcendência. "Este horizonte da transcendência está presente num modo exclusivamente seu, o modo da recusa e da ausência. Ele se dá a nós no modo da renuncia de si mesmo, do silêncio e da distância” (RAHNER, 1970, p. 181). A incompreensibilidade de Deus também é uma verdade a não ser esquecida, pois garante que não podemos dispor de Deus, nem com nossos conceitos mais elevados. A graça se dá na proximidade do mistério perene, apreendido como insondável (RAHNER, 1970, p. 188). A realidade de Deus está além do conceito. É preciso chegar à realidade de Deus sem se fixar obsessivamente no enunciado. 
Neste caso, soa oportuna para o diálogo inter-religioso a visão de Duquoc segundo a qual a Igreja não deve se apresentar como dona absoluta da verdade. Se de um lado ela não renuncia à verdade do Cristo que atua pelo Espírito, por outro, abdica da tentação de saber tudo sobre Deus e de impor a verdade de maneira totalitária. Reconhece, assim, as possíveis riquezas dos diversos fragmentos presentes nas tradições religiosas. A humildade epistemológica se mostra benéfica e salutar, porque permite uma unidade parcial ou uma "unidade na divisão", marcada mais por um projeto comum de justiça e paz do que por uma doutrina consensual. O adiamento da sinfonia faz despontar os fragmentos como "lugares paradoxais da esperança". Mas ele depende, sobretudo, da modéstia na compreensão da verdade sobre Deus, que, como afirma Rahner, se dá "na renúncia e na distância”.

\section{O Espírito, a salvação e a sinfonia adiada}

Duquoc adota a perspectiva pneumatológica para propor a sinfonia adiada. O Senhor se retrai para que o Espírito Santo aja. Sua proposta se revela pertinente também neste aspecto, porque o tema do Espírito Santo é primordial para a teologia das religiões e o diálogo inter-religioso. A dimensão universal da salvação de Cristo e sua mediação constitutiva se relacionam com a obra do Espírito Santo, que ultrapassa as fronteiras da Igreja. Os efeitos de sua presença são universais e não conhecem limites de tempo e espaço. Ainda que aja no corpo de Cristo - a Igreja - e nos seus membros de modo particular, sua ação é universal (LADARIA, 2009, p. 102). "O Espírito do Senhor enche o universo" (Sb 1,7). Sua tarefa consiste em conduzir a Igreja à plenitude da verdade (Jo 16,13) (LG 4). Se a Igreja deve ainda ser conduzida à plenitude da verdade, guiada pelo Espírito, cabe-lhe manterse aberta a uma verdade que a ultrapassa e cuja posse só se dará no fim, no momento da realização da sinfonia adiada.

Duquoc parte de um pressuposto que a revelação confirma: a tentativa de dominar o Espírito parece inútil. De onde ele vem, para onde ele vai? Não 
perquirimos totalmente sua ação misteriosa. "Pelo nome que tem o Espírito, sabese que jamais se poderá pôr a mão sobre ele para domesticá-lo. Tanto em hebraico (ruah), quanto em grego (pneuma) e em latim (spiritus), ele se chama o sopro" (DURRWELL, 1985, p. 12). O símbolo do Espírito é o vento (Jo 3,8). Há outros símbolos do Espírito: a água, o fogo, a pomba. Símbolos que exprimem o inefável. O Espírito, quando a razão quer objetivá-lo em conceitos e submetê-lo ao jogo das análises, escapa. Os muitos símbolos que aparecem na Bíblia e na Tradição para designar o Espírito demonstram a dificuldade para enquadrá-lo num conceito preciso. Segundo Durrwell (1985, p. 12), o Espírito na Trindade "é o mistério interior ao mistério".

A presença do Espírito em Jesus se encontra amplamente atestada no Novo Testamento (Mt 1,18.20; Mt 3,13-17; Mc 1,9-11; Lc 1,35; Lc 3,21-22). João Batista testemunha que Jesus é o eleito de Deus porque o Espírito desce e permanece nele (Jo 1,32). O messianismo de Jesus se manifesta quando sobre ele desde o Espírito Santo no Jordão, no momento do batismo, depois do qual ele se apresentará como o ungido de Deus, apropriando-se das palavras de Isaias 6,1: "O Espírito do Senhor está sobre mim, porque ele me consagrou pela a unção" (Lc 4,18). Tendo recebido o Espírito Santo, Jesus começa sua vida pública como messias sob seu impulso, realizando a obra do Reino a ele confiada pelo Pai (DURRWELL, 1985, p. 44-45). A presença do Espírito Santo em Jesus continua durante toda a sua vida. Do batismo em diante, exercerá todas as suas atividades movido pelo Espírito (At 10,38). Ele será o "cheio do Espírito Santo" (Lc 4,1) e agirá movido e sustentado pelo Espírito (cf. Mt 12,28). Na cruz, entrega-se ao Pai em virtude de um Espírito Eterno (Hb 9,14) e é ressuscitado na força desse mesmo Espírito que o constitui, na ressurreição, Filho de Deus com poder (Rm 1,4). Os tempos messiânicos se aproximam com a efusão do Espírito Santo pelo Senhor ressuscitado (At 1,16ss.).

Jesus, salvador em sua humanidade, torna-se o mediador do dom do Espírito, mas ele deve voltar ao Pai, viver no seio do Pai, a fonte do Espírito, para 
que possa enviar o Espírito. "No entanto, eu vos digo a verdade, é de vosso interesse que eu parta, pois, se não for, o Paráclito não virá a vós. Mas se for, envia-lo-ei a vós” (Jo 16,7). No Evangelho de João, Jesus é o depositário do Espírito (cf. Jo 1,32-34). Jesus, tendo voltado à sua glória, envia de junto do Pai o Espírito. Ao assumir a humanidade, ele se tornou a salvação dos homens, porém, para que a salvação chegue a todos, ele precisa enviar o Espírito. O fruto fundamental da ressurreição consiste exatamente na efusão do Espírito (LADARIA, 2009, p. 103-104). Não se compreende, assim, o Espírito sem Jesus, ele é “o Espírito de Jesus”, “o Espírito do Filho”, “o Espírito de Cristo”, “o Espírito do Senhor" (Fl 1,19; Gl 4,6; Rm 8,9; 2 Cor 3,17). O dom do Espírito Santo no Novo Testamento se destina à consumação da sua obra salvífica. Sua ação no mundo não se situa à margem da ação salvífica de Jesus.

Não há uma economia da salvação a não ser aquela que tem sua origem na iniciativa do Pai, o seu centro nos mistérios da vida, morte e ressurreição de Cristo, cujos efeitos chegam a todos os confins da terra graças à ação do Espírito, dom do Pai e de Jesus Cristo ressuscitado (LADARIA, 2009, p. 104).

A Igreja nasce do dom do Espírito que a faz continuar a missão do seu Senhor, sendo no mundo sacramento da presença real de Jesus e da graça da salvação trazida por ele. Ela sabe, no entanto, que o Espírito ultrapassa suas fronteiras, uma vez que o horizonte do Reino que Jesus anunciou (Mc 1,15) no poder do Espírito abrange o mundo inteiro. Ela não é o Reino, mas o seu gérmen, seu sinal no mundo. O Espírito do Senhor foi derramando "sobre toda carne" (Hb 2,17), em vista da realização universal do Reino (CODINA, 2008, p. 162).

Segundo Duquoc, a ação do Espírito se revela misteriosa, o que exige da Igreja atitude mais humilde quanto à ação do Espírito em outras religiões. Afinal, o Espírito atua em outras tradições religiosas, sem que seja necessário considerá-las “cristianismo anônimo". O respeito ao fragmento se impõe pelo simples fato de não sabermos o que, exatamente, o Espírito está realizando fora da Igreja. Segundo Codina (2008, p. 163), são muito atuais as palavras de Paulo aos Tessalonicenses: 
"Não extingais o Espírito, não desprezeis as profecias, examinais tudo e ficais com o que é bom" (1Ts 5,19). O Espírito se revela o autor de toda bondade presente no mundo, engendrada pelas várias tradições religiosas.

A Bíblia nunca fala de uma ação de Deus sobre o Espírito. Ele não é gerado, nem revelado, nem encarnado. Não é autor, nem efeito, ele é a operação, aquele por quem Deus gera, se revela e se encarna. Por isso a teologia afirma que ele procede do Pai. Emana como uma ação. Mas como conceber uma pessoa que é ação? "Ele é a graça pela qual Deus é gracioso, a salvação pela qual Deus é salvador, é o poder divino em sua atividade" (DURRWELL, 1985, p. 13). Se o Espírito se identifica com o poder no qual Deus faz todas as coisas, então "todos os atributos de Deu são hipostasiados no Espírito" (DURRWELL, 1985, p. 32). O Espírito é a glória, a santidade, o amor e a vida. O Novo Testamento vê em Jesus o homem do Espírito, nascido de Deus pelo Espírito (Lc 1,35). Jamais o Espírito se apresenta como o efeito de uma ação de Deus, ele se identifica com essa ação. O Espírito é, portanto, "o poder criador de Deus" (DURRWELL, 1989, p. 23). A Escritura mostra o Espírito como o agir onipotente de Deus, em quem são feitas todas as suas obras. O Espírito, que é a força operante de Deus na história, "poder hipostasiado", é também amor, "amor hipostasiado" (DURRWELL, 1989, p. 32)4. Os escritos paulinos relacionam o Espírito com a caridade de Deus (Rm 5,5).

Se o Espírito Santo é o "poder de Deus em ação", por conseguinte essa ação está presente no mundo, na história, nas outras tradições religiosas. Duquoc convida a Igreja a redimensionar tal verdade, renunciando à pretensão de antecipar a síntese final, como fez em outras épocas, provocando divisões negativas. A aceitação do fragmento como fruto do Espírito é propulsora de paz e solidariedade. Por um lado, nem sempre é fácil "discernir a presença do Espírito em pessoas, grupos, tendências, movimentos e ideologias, onde ela se mistura com limitações, erros, condicionamentos culturais, pecados, ambiguidades, egoísmos,

\footnotetext{
${ }^{4}$ João Paulo II (1986) afirma que o Espírito Santo é, em Deus, "amor essencial".
} 
interesses pessoais ou grupais" (CODINA, 2008, p 173); por outro, trata-se de uma tarefa importante se queremos avançar no diálogo inter-religioso. Se o Espírito está em operação nos fragmentos, todos os parceiros do diálogo carregam uma fundamental capacidade para a verdade e a teologia cristã também se deixa instruir por outras tradições religiosas. O parceiro cristão não se vê apenas como doador, é também receptor, de tal modo que o diálogo fecundo contribui para o enriquecimento de todos (BÖTTIGHEIMER, 2014, p. 343-344).

O amor, de acordo com a revelação cristã, se manifesta como o sinal inequívoco da ação do Espírito, afinal ele é “amor hipostasiado”. Uma vez que sua missão é tornar presente Cristo, conduzindo os homens à plena verdade, podemos afirmar que a presença do Espírito se dá, sobretudo, pela prática do amor, entendido como solidariedade desinteressada e ilimitada. A solidariedade samaritana. O Espírito, de um modo não totalmente conhecido, configura o mundo a Cristo pelo amor. A sinfonia adiada de Duquoc coincide, portanto, com a comunhão de todos os homens com Cristo e entre si pela ação do Espírito Santo. A sinfonia adiada de Duquoc só encontra sentido se a identificamos com a fraternidade universal, que coincide com o plano de salvação de Deus. O sinal inequívoco da antecipação - ainda que precária - da sinfonia adiada de Duquoc é a fraternidade, porque servir-nos uns aos outros por amor $(\mathrm{Gl} 5,14)$ resume o sentido da vida do ponto de vista do cristianismo. "O projeto de Deus é configurar uma humanidade que viva em comunhão fraterna, com a natureza e com Deus; é gerar uma koinonia inter-humana, cósmica e trintária” (CODINA, 2008, p. 162).

Segundo a teologia cristã, a graça diviniza o homem, filializando-o; seu destino é participação no próprio ser de Deus (2 Pd 1,4). O Espírito age nas várias tradições religiosas divinizando seus adeptos, mas só acolhem a ação do Espírito os que amam ou buscam amar radicalmente, afinal, quem pertence a Deus ama como Deus e só aquele que ama nasceu de Deus. Quem não ama mente (1 Jo 4). Só o amor testemunha a presença do Espírito, porque reflete o próprio Deus em nós. Todo amor que há no mundo sinaliza a presença do Espírito. Portanto, a presença 
de Deus nas outras tradições religiosas se verifica pelo amor. O papel da Igreja consiste em ser sacramento do amor de Deus aos homens na história. Sua mensagem se resume na contundente afirmação: todos somos irmãos. Ela aposta na fraternidade, sabendo que a vivência do amor traduz a essência da mensagem de Jesus. Fraternidade que suplanta o conhecimento explícito de Deus e do seu Cristo (Mt 25,31-46). Nesse sentido, a doutrina não deveria ser impedimento para o diálogo inter-religioso e a proposta de Duquoc se mostra consistente. As religiões são fragmentos da comunhão futura entre todos. E cada uma, na sua particularidade, está chamada a contribuir para que a paz e a justiça reinem no mundo, como sinais já presentes da sinfonia adiada, a fraternidade escatológica.

\section{Conclusão}

O diálogo inter-religioso desponta como novo horizonte para a teologia. Para Duquoc, tal diálogo se faz necessário em vista da paz e da justiça do Reino, o sonho de Deus para a humanidade. Mas o diálogo precisa se fazer sem arrogância epistemológica e sem a pretensão da totalidade da verdade. Só assim a Igreja estará em condições de acolher as outras tradições não somente como manifestações anônimas do cristianismo, mas como parte do projeto e da pedagogia de Deus, que atua "na renúncia e na distância", sem que possamos compreendê-lo totalmente com nossas categorias humanas, finitas e limitadas. A Igreja permanece sacramento do projeto salvífico universal de Deus, cujo ápice se encontra no mistério pascal de Cristo, do qual todos podem participar, pela ação misteriosa e imprevista do Espírito Santo. Aqui, Deus emerge como aquele que busca a salvação da humanidade, por meio da vida entregue do Filho e comunicada a todos pelo Espírito (CODINA, 2008, p. 215-216). O Espírito, do Pai e do Filho, é o caminho de salvação no cristianismo e nas religiões. Ele unificará numa partitura única as composições dispersas. A antecipação da sinfonia final encontra sua medida no amor, porque "todo aquele que ama nasceu de Deus e conhece a Deus. Aquele que não ama não conheceu a Deus, porque Deus é amor" (1 Jo 4, 7-8). 
Duquoc não explica como se dará, do ponto de vista da escatologia, a sinfonia final, que permanece ainda desconhecida. Ao não tratar do assunto, deixa a impressão de certo agnosticismo escatológico. Em todo caso, qualquer palavra sobre as últimas coisas é sempre penúltima. Cremos que a ressurreição de Cristo repercutirá de maneira plena na história e no cosmos. Toda criação participará de sua páscoa. A criação, sendo obra de Deus, não fracassará. Quanto à salvação final dos seres humanos e sua participação na vida eterna de Deus - communio sanctorum in communione Trinitatis -, a sinfonia adiada de Duquoc sugere a esperança de uma salvação universal, que englobe a todos. Esperança que não é certeza, porque, em última instância, ninguém sabe o que cada ser humano fez de si mesmo com sua liberdade. Ao cristão, no entanto, cabe esperar que cada vida humana alcance seu fim bom e feliz, afinal de contas, Deus criou o ser humano para si e tudo arriscou por ele (GRESHAKE, 2009, p. 184). A Escritura, segundo Balthasar (1997, p. 81), anuncia uma salvação capaz de unir, num único vínculo, todos os homens e reconciliar o universo inteiro. A sinfonia adiada, embora não afirme explicitamente a reconciliação do universo inteiro, acena para a esperança de uma salvação de todos em Cristo (Jo 3,17) por meio do Espírito.

\section{REFERÊNCIAS}

BALTHASAR, Hans Urs von. Gesù e il Cristiano. Milano: Jaca Book, 1998.

BALTHASAR, Hans Urs von. Sperare per tutti. Con l'aggiunta di breve discorso sull'inferno. Milano: Jaca Book, 1997.

BÍBLIA DE JERUSALÉM. São Paulo: Paulus, 2003.

BÖTTINGHEIMER, Christoph. Manual de Teologia Fundamental. A racionalidade da questão de Deus e da revelação. Petrópolis: Vozes, 2014.

CARDEDAL, Olegario González de. Cristologia. Madrid: BAC, 2008.

CODINA, Victor. "No extingáis el Espiritu” (1 Ts 5,19). Una iniciación a la Pneumatologia. Santander: Editorial SAL TERRAE, 2008.

COMPÊNDIO DO VATICANO II. Petrópolis: Vozes, 1983. 
DE LA PEÑA, Juan Luis Ruiz. Teología de la creación. Santander: Sal Terrae, 1988.

DUQUOC, Christian. Credo la Chiesa. Precarietà istituzionale e regno di Dio. Brescia: Queriniana, 2001.

DUQUOC, Christian. O único Cristo. A sinfonia adiada. São Paulo: Paulinas, 2008.

DURRWELL, François-Xavier. L'Esprit Saint de Dieu. Paris: Cerf, 1985.

DURRWELL, François-Xavier. L'Esprit du Père et du Fils. Paris: Médiaspaul, 1989.

GRESHAKE, Gilbert. Vita - più forte della morte. Sulla speranza cristiana. Brescia: Queriniana, 2009.

HERVIEU-LÉGER, Danièle. O peregrino e o convertido. A religião em movimento. Petrópolis: Vozes, 2008.

JOÃO PAULO II. Dominum et Vivificantem. São Paulo: Paulinas, 1986.

KESSLER, Hans. La resurrection de Jesus: aspecto bíblico, teológico y sistemantico. Salamanca: Sigueme, 1989.

LADARIA, Luis Francisco. El Dios vivo y verdadero: El mistero de la Trinidad. Salamanca: Secretariado Trinitario, 2005.

LADARIA, Luis Francisco. Gesù Cristo salvezza di tutti. Bologna: EDB, 2009.

LIBANIO, João Batista. Eu creio, nós cremos. Tratado da fé. São Paulo: Loyola, 2000.

RAHNER, Karl. Teologia e Antropologia. São Paulo: Paulinas, 1969.

RANHER, Karl. O dogma repensado. São Paulo: Paulinas, 1970.

TEIXEIRA, Faustino. Karl Ranher e as religiões. In: OLIVEIRA, Pedro Rubens F. de;

PAUL, Claudio (org.). Karl Rahner em perspectiva. São Paulo: Loyola, 2004. 